УАК 11:7.01

DOI: $10.26565 / 2226-0994-2020-63-22$

\title{
Семен Гончаров
}

\section{РОАЬ І МІСЦЕ ТАЕМНИЦІ В МЕТАФІЗИЦІ МАМАЕЕВСЬКОГО ХАОСМОСУ}

У статті йдеться про роль і місце Таємниці в структурі мамлєєвської метафізики. Автор статті залучає поняття «хаосомосу», введене Ажеймсом Ажойсом в експериментальному романі «Поминки за Фінеганном», Ао мамлєєвського Всесвіту. Це призводить до трансформації формули «хаос - осмос - космос», актуалізованої постмодерністським Аискурсом, у формулу «Хаос - Осмос - Космос». Хаос перетворюється на Сакральний Хаос як один із метафізичних проявів Росії Вічної. Осмос постає антиномічним російським життям, котре поєАнує в собі те, що неможливо поєАнати, а також ставить перед собою принципово нездійсненні завдання. Космос же відсилає до традиції російського космізму 3 його проблемою віАповіАності мікрокосму та макрокосму. Автор статті зазначає, що всепроникливим і всеєднальним елементом мамлєєвського хаосмосу є саме Таємниця. Вона - одна 3 п'яти стрижневих метатем мамлєєвської творчості, ii особливість полягає в пов'язуванні між собою інших метатем: утризму «Я», Смерті, Безодні та Росії. У площині утризму «Я» Таємниця розглядається як таємниця самої Аюдини (iі «вищого Я»). Зі Смертю Таємниця пов'язана запитуванням Аюдини про вцасну Аолю та скінченність. Проблема подолання смерті та жага до вічного життя - центральні теми, які турбують майже всіх героїв мамлєєвських романів та оповіАань, а Аля самого Мамлєєва вони є витоком ціннісних установок, спрямованих на досягнення Аюдиною «вищого Я». Найбільш міцним і принциповим ААя Мамлєєва є зв'язок Таємниці й Безодні, а також зв'язок Таємниці та Росії. Розгляд вказаних зв'язків спонукає автора зробити висновок про те, що Юрій Мамлєєв описує такі виміри Таємниці, які виходять за межі введених С. $\Lambda$. Франком категорій «незбагненного Аля нас» $\mathrm{i}$ «незбагненного по суті». Це зумовлює необхілність введення нових понять, які б розкривали сутність мамлєєвських новацій більш влучно. Автор статті пропонує розгАядати Безодню як «Останню Таємницю» на тій піАставі, що вона є трансцендентною до самих трансценденцій, тобто виходить за межі Абсолюту; а Вічну Росію як Росію-Таємницю на піАставі того, що Мамлєєв надає їй статус третього метафізичного Початку поряд з Абсолютом і Безоднею.

Ключові слова: Мамлєєв, Таємниця, Безодня, хаосмос, незбагненне, космізм.

But the spoil of hesitants, the spell of hesitancy. His atake is it ashe, tittery taw tatterytail, hasitence humponadimply, heyhey-heyhey a winceywencky. Assembly men murmured. Reynard is slow! ${ }^{1}$ James Joyce. Finnegans Wake

Ксюша вАруг рассердилась: - Хаоса у вас мало! И смерть свою вы не Аюбите! Потаповы обомлели, как буАто Ааже ростом стали помельче. А деА Игорь убёг.

Юрий Мамлеев. Мир и хохот

О! страшных песен сих не пой! Про Аревний хаос, про родимый Как жадно мир Ауши ночной Внимает повести Аюбимой! Из смертной рвется он груди, Он с беспредельным жаждет слиться!.. О! бурь заснувших не буди Под ними хаос шевелится!..

Федор Ттотчев. О чём ты воешь, ветр ночной?.

1939 року з'явився найскладніший та найбільш експериментальний роман Ажеймса Ажойса «Поминки за Фіннеганом», що створювався автором протягом

(C) Гончаров C. O., 2020.

$(\mathrm{cc}) \mathrm{Br}$ This is an open-access article distributed under the terms of the Creative Commons Attribution License 4.0.

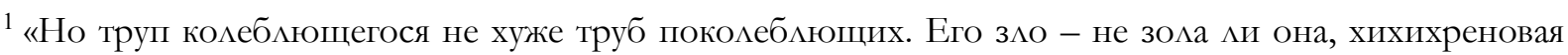
трясогоглемогольская фэй-ей-ей фланель на панель. Собрание забормотало. Ренар устал» (переклаА російською - Анрі Волохонський). 
шістнадцяти років за Аопомогою техніки «потоку свідомості» 3 використанням різноманітних мовних запозичень (з китайської, японської, російської та багатьох інших мов), вибудованих у нескінченний манцюг макаронізмів, каламбурів і неологізмів. Створений Ажойсом текст став справжнім пеклом Аля читачів (чим він є Аля переклаАачів, навіть уявити склаАно, оскільки у всіх планах він є неперекладним). Мабуть, узагалі не існує Аюдини, яка б могла зрозуміти його повною мірою, аАже навіть сам автор забував сенс певних фрагментів наприкінці в ласної роботи.

Саме там уперше з'являється поняття «хаосмосу» як поєАнання хаосу (віАсутності буАь-якого порядку), осмосу (потенційного поряАку, процесу Аифузіі) і космосу (вищого, небесного порядку) в єАине ціле, що пізніше увійшло до широкого захіАного постмодерністського вжитку. Цей складний конструкт має щонайменше Ава актуалізовані виміри, обидва 3 яких констатують той факт, що його потенції до продукування сенсу безмежні. Перший - це погляА на сам текст Ажойса як на втілення іАеї хаосмосу, що є абсолютно Аоцільним, оскільки сама структура роману є коливанням між повним безАалом i ретельно сконструйованим порядком із їх взаємопроникненням та Аіалогічною грою, в якій досягається певна гармонія (хоча сліА зауважити, що через внутрішню множинність форм і склаАність Аля сприйняття у тексті Ажойса може вбачатися певне домінування саме хаосу, що іє модерністським акцентом).

Інший вимір - це постмодерністський Аискурс, який помічає виключну влучність хаосмосу як можливого відображення (поряд із «ризомою») нової ситуації, в яку потрапляє суспільство наприкінці ХХ століття. Характеристиками такої ситуації стають: нелінійність, несистемність, рухливість, множинність, неієрархічність тощо (що також передбачає віАкритість самого хаосмосу до безмежного впорядкування, тобто постійної появи та зникнення сенсів). ВіАповіАно до такої віАкритості хаосмос можна розглянути і в площині радянського та пострадянського простору, а саме в контексті творчості метафізика Юрія Мамлєєва.

Метою статті є визначення ролі та місця Таємниці в структурі мамлєєвського хаосмосу.

Завданнями статті є розгляА результатів інтеграції поняття хаосмосу у творчість Мамлєєва, визначення особливостей мамлєєвської філософіï у площині Таємниці, детальний аналіз зв’язку Таємниці та Безодні, а також Таємниці та Росіі.

Застосування поняття «хаосмосу» до мамлєєвської творчості є Аосить продуктивним, оскільки Аозволяє комплексно охарактеризувати мамлєєвський мітературно-філософський проєкт. Найперше, що можна віАзначити, це співвіАнесеність між мітературною основою поняття «хаосмосу», яке народжується саме через роман, і надзвичайною важливістю художнього тексту як транслятора метафізики Аля Юрія Мамлєєва, філософія якого розцита, серед іншого, і в його романах та оповіАаннях.

По-друге, сама сутність хаосмосу віАповідає характеру й духу того масштабного полотна російського життя та російської ментацьності, яке описує у свої творах Мамлєєв. Такі риси, як особлива хаотичність (така хаотичність, яка, з одного боку, не містить жодного розумного порядку, а з іншого - за Аопомогою наАраціональному погАяАу може

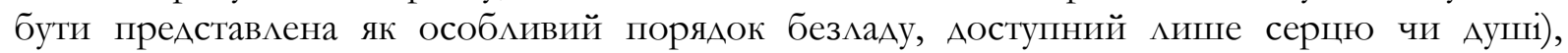
ірраціональність, безмежність, безцільність, схильність до крайнощів, Аивне співіснування

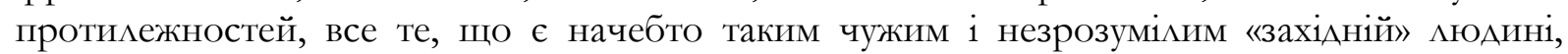
значною мірою вілповіАає хаосмосу. МожАивим це є завАяки вже зазначеній здатності самого хаосмосу до продукування сенсів, а також через той факт, що роман «Поминки за Фіннеганом» є радикальним міжнаціональним (за залученням мов) модерністським (тобто таким, що руйнує чинні норми) поліфонічним експериментом.

Найголовнішим серед того, що дає залучення хаосмосу до мамлєєвської творчості, $€$ можливість вираження особливого поєАнання російського космізму та хаосу як основоположного принципу російського буття. 
Тобто формула «хаос - осмос - космос» трансформується у формулу «Хаос - Осмос - Космос», набуваючи нового змісту:

- хаос стає Сакральним Хаосом («хаос» підвищується до «Хаосу»), який є водночас одним із семи метафізичних проявів Росії (однією зі сторін Вічної Росіi), а також одним 3 п’яти концентрів втіменої Росіі;

- осмос у такому разі виступає антиномічним російським життям, яке об’єАнує в собі те, що принципово не може бути об’єАнано, тобто це буття всередині російського топосу, що втілюється через хаос (причому Хаос сприймається як свій, ріАний) у процесі віАкилання раціональних обмежень i виходу на налраціональний рівень. Саме налраціональність і металогічність осмосу, його направленість на трансцендентне АОзволяють позначити його як «Осмос», наголошуючи цим на віАриві віА раціоналізму буденності та прагматизму як національної російської особливості;

- космос же віАсилає до традииї російського космізму з ії проблематикою всеєАності, пошуком місця Аюдини у Всесвіті, розглядом зв'язку земних і космічних процесів на основі поєАнання науки, філософіï, релігії, мистецтва, а також езотерики та містики. Сам Мамлєєв пише про космологічну Росію як один із вимірів Росії Вічної: «Сенс < ..> відношень (між Росією та Безоднею) настільки грандіозний, що виходить за межі будь-якої світової історії, тому неминуче Росія переростає межі цюдської історії, і вона, віАповіАно, є космологічним явищем» (тут і далі переклаА мій. - С. Г.) [Мамлеев, 2011, с. 211]. Через власну наповненість і глибинність «Космос» теж передбачає написання з великої мітери, оскільки він не мише виступає як опозиція до Хаосу, але й втілює в собі безмежність, яка, незважаючи на множинність форм, зберігає власну єАність.

Недарма Мамлєєва називають російським космістом, адже вся його увага прикута до магічного російського топосу, в якому «бувальщина живе і небилиця», котрий зображується в його романах і оповіАаннях яскравими шокуючими барвами. Ось як він характеризує Хаос: «Хаос - це світова, космічна потенція, яка затаїлася, і в якій непередбачуване та нерозкрите знаходиться у стані по той бік Порядку. Хаос з його необмеженими можливостями вривається у Світовий Порядок, деформуючи його, руйнуючи і водночас вливаючи в Космос нові фантастичні сили й тенденції. Очевидною є присутність Хаосу в російській історії, культурі, Ауші <..> “РіАний хаос" у нас відчувається навіть у наших безмежних просторах, у мові (з ії відхиленням віА суворої логічної побудови, 3 іï несподіваними проривами у сферу метафізично невизначеного), у нашому способі життя (з його Аякаючою і привабливою Аля іноземців ейфорією та випадінням із буденного раціоналізму)...» [Мамлеев, 2011, с. 155-156].

Проте неможна зупинятися на розгляді кожного окремого елемента хаосмосу, необхіАно зазначити також принципову єАність цих трьох елементів, яка зображена у вигляді проміжних тире («-») у формулі «Хаос - Осмос - Космос». Така особлива єдність віАсилає до мамлєєвського бачення Росії як третього метафізичного Початку, що зв’язує Абсолют з Безоднею, тобто «поєднує непоєднуване» [Мамлеев, 2011, с. 267]. Це повністю віАповіАає антиномічності самого поняття «хаосмосу», що єАнає в собі потужні протилежності, які, відштовхуючись, водночас і притягуються.

Отже, можна констатувати, що поняття «хаосмосу», введене Ажойсом, резонує 3 характером мамлєєвського проєкту, i в разі застосування до останнього розкриває як власний потенціал безмежного впорядкування (за відсутності оприявленого порядку), так і стимулює до розкриття сам Аискурс мамлєєвської метафізики, яка в такій взаємодії розширює спектр власних проявів і рефлексій.

Ані Сакральний Хаос, ані релігійно-філософський космізм не можуть бути розглянуті без осмислення та залучення Таємниці, Ао якої постійно звертається Мамлєєв як безпосередньо, так і через персонажів власних романів та оповіАань. Їі суттєвість Аля мамлєєвської системи координат віАзначалася нами раніше: Таємниця вже була виокремлена як одна зі структуротвірних $\mathrm{i}$ ключових метатем всієї творчості 
Юрія Віталійовича [Гончаров, 2019, с. 75], проте залишається потреба в розгляді метафізичних вимірів Таємниці, а також піАходів до їх осмислення.

У своїй фундаментальній роботі «Незбагненне» С. $\Lambda$. Франк так пише про буття: «Буття як таке, у його безумовності, і таємниця є просто одне й те саме. Водночас “таємниця" означає тут не загадку, котра потребує вирішення (хоча б це вирішення фактично було Аля нас неможливим), а “таємниче" по самій своїй природі, точніше трансраціональне - те, що по своїй суті є протилежним до всього збагненного» [Франк, 1990, с. 279-280]. А ось що зазначає Юрій Мамлєєв як головне завдання «метафізичного реалізму», традицію якого він започатковує: «... метафізичний реаліст $<\ldots>$ має бути наАреалістом, що, звичайно, включає як початковий момент гАибоке знання виАимого життя $<\ldots>$ ОАнак це знання виАимого життя має бути А^я нього Аише початковим моментом, за яким віАкривається його проникнення в більш грізну реальність $<\ldots>$ по суті, видиме життя Аля такого письменника стає символом або аналогом вищих (або, навпаки, інфернальних) реалій, котрі $<\ldots>$ повинні виступати оголено, Аоступно, віАтісняючи на задній план зображення нижчої реальності та Ааючи читачеві нічим не прикрите бачення безодень...» [Мамлеев, 2006, с. 101-102].

У наведених цитатах можна побачити загальний Аля Авох мислителів вектор - це Аослідження метафізичної глибини буття, котре сповнене невідомим i виступає як принципова Таємниця, осягнути яку і жадає мюдина. Тобто Таємниця стає певним орієнтиром, навіть методом. Корінь такої методологічності Таємниці знаходиться у фундаментальному розрізненні «незбагненного для нас» і «незбагненного самого по собі» («незбагненного по суті») [Франк, 1990, с. 197], яке вводить Франк у роботі «Незбагненне». Він зазначає, що принциповим є існування не мише того, що незбагненне Аля нас через недосконалість нашого пізнання, але й незбагненне, сутністю якого є сама незбагненність, яка виступає метафізичною константою.

Схожим на це є розрізнення секрету і Таємниці, яке випливає зі слів Франка. У цьому разі Таємниця принципово віАрізнясться віА секрету тим, що вона знаходиться в метафізичній площині, маючи трансцендентний вимір, водночас секрет не виходить за межі іманентного, фігуруючи виключно у сфері буденності: «Таємниця - не секрет, що розгадують, щоб оволодіти їм Аля себе, вона може частково віАкриватись лише істоті, котра зАатна до інтелектуальної та Ауховної напруги» [Кордас \& Николаева, 2015, с. 18]. Тобто секрет ми зАебільшого розуміємо як приховану віл нас інформацію, якою через певні життєві обставини ми не володіємо, залучення ж Таємниці передбачає філософський Аискурс метафізично-гносеологічної проблематики широкого Аіапазону: віА когнітивних АосліАжень Ао містичних АОктрин.

Яким же чином про Таємницю можна говорити як про метод, якщо вона в звичному уявленні представляється як об'єкт пізнання, тобто те, на що якраз і має бути спрямований певний метод? Річ у тім, що як Франк, так і Мамлєєв постійно наголошують на обмеженості раціонального, суто понятійного пізнання, а їхні філософські зусиляя направлені на подолання такої обмеженості та розкриття тих сфер, де вказане пізнання втрачає вцасний сенс. КАючовим же стає введений Франком вимір саме «незбагненного по суті», щодо якого просто неможливо застосувати понятійно-категоріальну сітку розуму, тобто наукове мислення. Така неможливість спирається на те, що незбагненне саме по собі - це трансдефінітне, трансфінітне та безумовне абсолютне буття [Франк, 1990], що a priori порушує будь-які правила Аогіки. Проте ми все одно стикаємося та взаємодіємо 3 незбагненним по суті, тобто певною мірою воно все ж якось нам дається. У такому разі ми стикаємося 3 одкровенням як містичним актом наАраціонального осягнення буття та зустріччю 3 нумінозним, АосвіАом якої стає АосвіА «присутності таємниці». Ретельне АосліАження цього АосвіАу знаходимо в роботі Рудольфа Отто «Священне», де зустріч $з$ нумінозним характеризується як mysterium tremendum i mysterium fascinosum - містичний жах і містичне захоплення [Отто, 2008]. 
Принциповою ж Аля оАкровення $є$ активна присутність самої Аюдини, іiі відкритість до подіі, екзистенціальна залученість на емоційному та духовному рівнях, навідміну віА наукового пізнання, яке характеризується певною віАстороненістю, «сухою раціональністю». Отже, у площині Таємниці, а саме тієї їі сторони, яка може бути зістав ена з Франковим «незбагненним по суті», звична схема пізнання «суб’єкт пізнання акт пізнання (інтенціональність) - об’єкт пізнання» втрачає сенс. Прірва між суб’єктом і об’єктом руйнується, натомість виникає відношення віч-на-віч, Аюдина не відчуває себе самотньою та покинутою, а віАкриває власну сутність через залученість до діалогу. Причому Таємниця не втрачає своєї таємничості, вона не схоплюється системою понять, не стає Аоступною Аля розуму, а розкривається у спроможності Аюдини до спів-буття 3 нею. Тобто Таємниця стає водночас усіма трьома елементами - суб’єктом, об’єктом і самим пізнанням. У суб’єкті вона втілюється через спроможність Ао зближення 3 абсолютним буттям, а також у відчутті подолання меж власного «Я». Як об’єкт пізнання Таємниця є

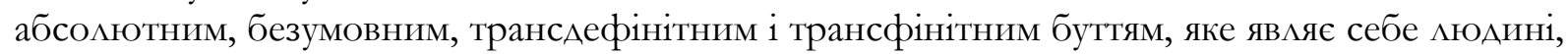
йле їй назустріч; а саме пізнання в такому разі - це Таємниця єАнання конкретного суб’єкта пізнання з абсолютним буттям, яка всіма сторонами є містичною та загадковою. Отже, методологічність Таємничі полягає у зміні погляду на пізнання: воно розглядається не як схоплення, привласнення, рачіоналізауія, але як подія зустрічі, момент становлення діалогу, ситуауія спів-буття.

НеобхіАно зазначити різницю акцентів Франка та Мамлєєва щодо Таємниці, а також Аетально розглянути той принциповий крок, який зАійснює Мамлєєв, створюючи «Останню Аоктрину». Аля Франка принципово важливою є присутність Іншого та віАношення «Я-Ти», тобто значну увагу він приділяє Аискурсу філософіï Аіалогу (М. Бубер, Ф. Ебнер, Ф. Розенцвайг). У Мамлєєва ж кАючовим є утризм «Я», котрий не передбачає фігуру Іншого як серйозну метафізичну величину. Це призводить до проблеми поєАнання утризму «Я» з метафізикою Росії, що є не менш суттєвою частиною мам єєвської філософії. Тобто перехіА віА «Я» до Росії (зокрема і в іiі іпостасі «Ми») віАбувається без залучення проміжного елементу, яким має виступати Інший («Ти»), що було розглянуто нами раніше [Гончаров, 2020, с. 144-145].

Утім, якщо мислення Франка рухається в напрямку розкриття теми Аюдини і Бога, повністю залишаючись у межах Абсолюту, то Мамлєєв створює вчення про Безодню, яка знаходиться поза Абсолютом і є непідвладною його законам. Це викликає необхіАність Аоповнення погляду на Таємницю як на Аворівневий конструкт («незбагненне Аля нас» $\mathrm{i}$ «незбагненне по суті»). Через те, що Безодня є трансцендентною до трансцендентного, а Абсолют стає певним «вікном» до безмежних метафізичних подорожей, виникає те, що вже не може бути зведене до незбагненного самого по собі. ОАнак не зовсім доцільно буде виділяти третій вимір Таємниці, адже в такому разі це стане продовженням за аналогією, а принципова відмінність Безодні буде втрачена. Якщо перші Ава виміри Таємниці можна розташувати в ієрархічному порялку (очевилною є метафізична домінанта неосяжного самого по собі як безумовного абсолютного буття, якому підпорядковані всі предметні сфери, тобто суще, яке АосліАжується наукою), то потенційний третій вимір, що має описувати Таємницю Безодні, є потойбічним щодо самої запропонованої структури. Саме через це доцільніше буле говорити про особливу Таємницю - Останню Таємницю (Таємницю Безодні).

Така Таємниця радикально відрізняється навіть віА найбільш прихованих і непрояв ених моментів абсолютного буття. Вона відображає прагнення виходу за всі наявні межі, зокрема й божественні. Водночас зіткнення з Безоднею вже не може бути описане за Аопомогою введених Рудольфом Отто категорій mysterium tremendum i mysterium fascinosum, воно взагалі ніяк не може бути виражене прямо - говорити можна мише про його певні натяки та віАгомони. Слово «Остання» віАсилає до «Останньої Аоктрини» - заключного розділу роботи «Аоля буття», Ае Мамлєєв розробляє вчення про Безодню та взаємодію з нею - «Останні віАносини». 
Яскравим прикладом ситуації випадіння 3 Абсолюту може бути історія Станіслава Нефьодова - головного героя роману «Світ і регіт» [Мамлеев, 2008]. Станіслав на певний час зник із буття та перестав функціонувати в парадигмі Абсолюту, тому навіть смерть не ста^а його кінцем - він «пережив» ii,, наче оАну 3 власних можливостей. Протягом усього роману родичі та Арузі Станіслава вАаються до найглибших метафізичних та езотеричних пошуків із залученням найрізноманітніших містиків i науковців, щоб знайти його, проте ніщо не може їм допомогти, оскільки сфера, в яку потрапив Станіслав, перебуває не мише поза раціональним, але й поза нацраціональним, тобто за межами наявної духовної Традиції. Повернувшись дивним чином у парадигму свого звичного життя, головний герой, утім, не в змозі розповісти про отриманий АосвіА, оскільки останній є принципово іншим щодо АюАського мислення та буття загалом, саме тому Станіслав мише зазначає, що відчував неймовірну відчуженість віА усього, що його оточувало в цьому іманентному світі. Тобто можна казати, що з ним віАбулась небачена Ауховна трансформація, проте вона не тільки не віАповіАає принципам іманентного, але й не зводиться до зустрічі з трансцендентним - ії природа інша. [Мамлеев, 2008]

Також сліА зауважити, що незважаючи на досліАження незбагненного, яке потребує подолання класичних природничо-наукових установок, текст С. $\Lambda$.Франка є Аосить наукоподібним, оскільки він ретельно упорядкований, посліАовно-логічний, має виважену Аискурсивну направленість, яка виражається в залученні різноманітних філософських концептів і постійному оперуванні філософсько-науковими поняттями. Тобто сама форма викладу ніби певною мірою суперечить змісту. I недивно, аАже сухе філософське міркування, навіть якщо воно і має власним предметом щось ірраціональне, завжди буде виглядати, як наукова доповідь, Ае сама сутність непізнаного, іншого, незбагненного буде неодмінно упорядкована різноманітними філософськими поняттями («трансфінітність», «трансдефінітність», «металогічність» тощо). Натомість Мамлєєв не обмежується такою формою виклаАу і наАає власній метафізиці ще й художню форму, що Аозволяє за Аопомогою насамперед образних метафор глибше розкрити ті пласти реальності, які не можуть бути схоплені в понятті. Взагалі, важливість метафори Аля дискурсу Таємниці є наАзвичайною і потребує окремого дослідження, тому зараз зазначимо мише той факт, що через метафору, серед іншого, розкривається естетичний аспект Таємниці.

М. Н. Марджи, визначаючи Таємницю як «синтез когнітивного, ціннісного та емоційного аспектів свідомості» [МарАжи, 2017, с. 280], розглядає способи ії вираження та осягнення, розрізняючи водночас містичне (міфологічне) та естетичне сприйняття Таємниці. У першому випадку емоційні переживання домінують наА когнітивною скцаАовою пізнання, унасліАок чого актуалізується особистісний аспект Таємниці, натомість у Аругому - піАкАючаються когнітивні структури, а також творча уява, що призводить до активації взаємин між суб’єктом і образом. Тобто в Аругому випадку осягнення Таємниці передбачає створення художніх засобів іiі вираження, віАтворення іiі за Аопомогою емоційно-естетичних образів [Марджи, 2017, с. 281]. Саме це ми можемо спостерігати у творчості Ю. Мамлєєва, і саме це стає художнім принципом, основою «метафізичного реалізму».

Тепер можна безпосередньо звернутися до питання про роль і місце Таємниці в метафізиці мамлєєвського хаосмосу. ОАразу необхіАно зазначити, що взагалі важко переоцінити важливість Таємниці в контексті мамлєєвського світобачення. Це пов'язано $з$ тим фактом, що Таємниця Аля Мамлєєва - це всепроникливий та всеєднальний елемент його Всесвіту. Структура «хаос - осмос - космос» є можливою як єАиний конструкт Аише завдяки Таємниці, оскільки сама собою вона є єАністю протилежностей, ії природа - це природа парадоксу, оксюморону. Така особливість є загальною, тобто стосується всіх вимірів наведеної схеми; у полі ж нашої уваги наразі перебуває той варіант останньої, який був зазначений нами на початку і який стосується творчості Ю. Мамлєєва, а саме: розуміння хаосу як Сакрального Хаосу, Осмосу як способу буття в антиномічному нацраціональному форматі, а Космосу як традиції російського філософсько-містичного 
космізму («Хаос - Осмос - Космос»). Усі ці три елементи, як і їх поєАнання, не можуть бути мислимі без урахування Таємниці.

Хаос отримує статус «Сакрального», тобто він постає не як звичайна опозиція до порядку, що відповіАає науковому світосприйняттю, а визначається як божественна містична сила, котра носить трансцендентний характер, тобто постає як вища Таємниця, оскільки вона зАатна руйнувати Світовий Порядок і насичувати його новими тенденціями. Осмос - це російське життя, в основі якого межить спрямованість на Таємницю, тобто бажання Іншого (потойбічного, небаченого), неймовірна жага до метафізичного свята, природний потяг Ао прихованого, що яскраво розкривається на всіх рівнях російської культури. I Космос, який є тим безкраїм простором, де розгортається містерія Таємниці, Ае Таємниця знаходить своє втілення у нескінченних дивах і парадоксах. Космос - це чарівний міс, сповнений дивовижних істот, спів-буття яких стає наративно-творчим порядком. I найголовніше - сама можливість цих трьох елементів не втрачати власну автономність, утворюючи водночас абсолютну єдність, є Таємницею, подібною Таємниці Святої Трійці.

Такі функції, як всепроникнення та всеєАнання, проявляються в Таємниці зокрема і як у певній метатемі, оскільки вона зближує між собою всі інші метатеми: утризм «Я», Смерть, Безодню, а також Росію [Гончаров, 2019, с. 74-76].

Утризм «Я» базується на «Я» як метафізичній першооснові, тому кАючовим у ньому

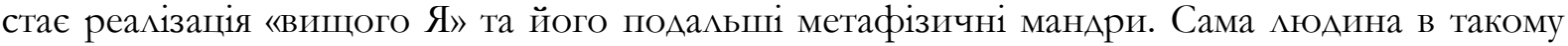
разі явцяє собою Таємницю, яку треба осягнути, з якої все починається і якою все закінчується. Аельфійська максима «пізнай самого себе» розкриває тут свої найглибші та найприхованіші аспекти. Аюдина - Таємниця Аля самої себе не мише в просторі іманентного буття, але й трансцендентного (3 можливістю подаАьшого руху поза Абсолютом).

Таємниця Смерті є очевидною, оскільки інтерес до смерті та спроби ії подолання виходять за межі мамлєєвських рефлексій і є однією з фундаментальних основ будь-якої культури. Тут можна мише вказати, що Мамлєєв постійно знаходиться у форматі memento mori: у романах і оповіданнях Мамлєєва смерть - це основна проблема, принциповий виклик, головна тема Аля Аискусій, оскільки ії бояться, ненавиАять, Аюблять, Аолають, віА неї тікають, з нею розмовцяють, ії пізнають і наА нею насміхаються, тобто вона майже завжди перебуває в полі уваги, і навіть тоді, коли розповідь віАходить віА неї, іі присутність відчувається на рівні неусувного фону. Сам Мамлєєв не перестає наголошувати на необхіАності Аосягнення безсмертя, на потребі реалізації «вищого Я» та віАмови віА усього матеріального й минущого. Така жага Ао безсмертя робить його близьким Ао найвідомішого російського косміста М. Федорова з його «Філософією спільної справи».

ОАнак, мабуть, найбільш міцним і суттєвим є зв’язок Таємниці з Безоднею та Таємниці з Росією. Оскільки Безодня межить поза Абсолютом, то іiі справедливо можна назвати Тасмницею Тасмниц - тією сферою, де навіть трансцендентне металогічне абсолютне буття не має сили, тобто така Таємниця є таємницею навіть Аля самого Бога. Через таку радикальність і була виділена особлива Остання Таємниця (Таємниця Безодні). Не менш суттєвим є зв'язок Таємниці з Росією: Аля Мамлєєва він має принципове значення і тому теж потребує окремого та більш розгорнутого розглялу.

Осмислення метафізики Росії Юрій Мамлєєв зАійснює у своїй фундаментальній праці «Росія Вічна». Там він вдається до аналізу всієї російської культури: мітератури, філософії, релігії та поезії. Особливу увагу він приліляє останній і саме вона найбільш яскраво відображає зв'язок Росії та Таємниці. Незбагненність і неосяжність, містичність і парадоксальність, прихованість і дивність - все це зображується в низці культових мотивів найрізноманітніших авторів, яких залучає та інтерпретує Мамлєєв: «Розумом Росію не зрозуміти...» (Тютчев), «I в таємниці спочиває Русь» (БАок), «Але Батьківщино, кагіАна! А за що - розгадати не можу!» (Єсенін), «А, можливо, Росії взагалі немає» (Іванов) [Мамлеев, 2011]. Такі поетичні мотиви наочно демонструють тенденцію, 
до якої з іншого боку підходить і російська філософія (Бердяєв, Хом’яков, Аеонтьєв, Аанилевський та інші), про яку Мамлєєв пише так: «Взагалі російська філософія самобутня насамперед тим, що в певному іiі напрямі сама Росія стає в ній “об'єктом” філософії < .. > Такого (стосовно власної країни) ніде не було» [Мамлеев, 2011, с. 100] (Ао речі, саме це може бути однією з причин розглядати філософію Ю. Мамлєєва як можливе продовження традиції російської релігійної філософії ХІХ століття).

Тобто ми маємо справу з особливим начіональним пошуком, який робить Росію запитуванням щодо самої себе, визначаючи водночас російське буття (Осмос), яке передбачає глибоке занурення в метафізику, зневагу до буденного зАорового глузду, а також намагання віАповісти на фундаментальні неосяжні питання (що є постановкою переА собою нездійсненних завдань). Це Аозволяє говорити про Росію як одвічне питання, на осмислення та вирішення якого спрямовані всі сили ії культури та науки. Така тенденція зміцнюється самою філософією Юрія Мамлєєва, в якій він впроваджує концепт Вічної Росії, що має сім метафізичних проявів: «свята Русь» (православ'я), російська культура, «Аруга реальність» і російське буття, невидимий світогляА, Сакральний Хаос, Русь Сходу (Русь Самопізнання), «Останні віАносини». Всі ці прояви пов’язані з Таємницею, без якої їх неможливо уявити.

Християнство є релігією особистого спасіння, в якій Ауша Аюдини остаточно не розчиняється в Абсолюті, а зберігає власну автономність, тому воно є релігією таємниці особистості (у найвищому сенсі цього слова), що є принциповим Аля Мамлєєва. Також він зазначає, що православ'я, як віАносно молодий Ауховний шлях, має особливу місію оновцення та озАоров ення світової культури, тому його таємниця - це майбутнє розкриття можАивостей АюАського Ауху.

Російська культура сповнена дивовижних, неповторних і таємничих пошуків сенсу АюАського життя та істини, що віАтворюеться у творчості цілої низки письменників: Аостоєвського, Толстого, Пцатонова, Гончарова, Горького та багатьох інших. Тобто можна сказати, що Таємниця притягує Ао себе російського генія, навіть поглинає його (згадаймо мише Федіра Михайловича Аостоєвського 3 його зануренням Ао глибин Аюдської Ауші з усіма ії висотами та низинами).

«Аруга реальність» $\mathrm{i}$ російське буття $е$ зАатністю російського топосу Ао формування прихованих, невидимих мандшафтів та водночас здатністю російської Ауші жити невидимим, надаючи йому безумовний пріоритет наА матеріальним i виАимим: «... головна риса [“Аругої реальності”] - певне випаАіння $з$ раціональної поверхні життя. Я маю на увазі, звісно, не "містику" чи “прозріння" і под. (це зовсім інше), а саме випадіння в "межах буденного життя", яке може відбуватись і зі “звичайними" Аюдьми, хоча в Росії немає “звичайних” мюдей...» [Мамлеев, 2011, с. 230]. Невидимий світогляд відображає потужне Аохристиянське минуле Росіі, часи язичництва, тобто приховану малодосліАжену історію, яка сповнена несподіванок і постає як таємна історія.

Сакральний Хаос і «Останні ВіАносини» (які є відносинами з Безоднею) детально вже розглядались нами [Гончаров, 2019, 2020], а Русь Сходу (Самопізнання), за Мамлєєвим, передбачає використання екзотеричних та езотеричних знань, що знаходяться у схіАній метафізиці, яка є унікальною через безліч прихованих і непроявлених вимірів та потенцій. Мамлєєв вважає, що Аосягнення схіАної культури близькі Росії, принаймні вони є набагато ближчими, ніж захіАні, а тому вони мають бути залучені до російських Ауховних пошуків і перероблені в російському духовному ключі [Мамлеев, 2011, с. 243]. Тобто схіАна культура, зокрема культура Індії (наприклаА, Веданта), є потужним джерелом Таємниці, яка охоплює все видиме й невидиме.

Проте найважливіший крок, АО якого вАається Юрій Мамлєєв щодо Росіі, полягає в наділенні іï статусом третього метафізичного Початку поряд з Абсолютом і Безоднею: «Але зі всіх антиномій Росії та Російської Ауші - найбільша за своїм

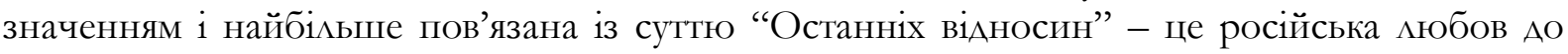
буття (у найширшому сенсі, не Аише Ао “землі”) та пристрасть до позамежного (Антиномічність такого поєднання є очевидною: позамежне може вийти за межі 
будь-якого буття або, звичайно, наявного буття.) $<\ldots>$ ЗвіАси вже на вищому метафізичному рівні стає зрозумілим ствердження Росії як Великого Посередника між Абсолютом (як Ажерелом Буття) і Безоднею “поза” Ним. Ба більше, сам Посередник (тобто Вічна Росія та ії втікення) у цьому канцюзі набуває фундаментального значення третього метафізичного Початку - Початку основоположного, як і перші два, оскільки, "поєАнуючи непоєАнуване", Росія набуває особливих якостей, котрі, віАрізняючи iii і віА Абсолюту, і віА Позамежної Безодні, визначають ії буття як третій метафізичний Початок» [Мамлеев, 2011, с. 266-267].

Таке важливе метафізичне та космологічне положення, а також все, що було зазначено раніше, свідчить про те, що Росія повинна мати власну Таємницю, яка не буде збігатися 3 Таємницею Абсолюту (наближення до якої розкривається у всіх релігійно-духовних традиціях богопізнання та богошукання; наприкцаА, у феномені таїнства як зустрічі 3 невидимою божою благодаттю, що веде до внутрішньої трансформації мюдини, розкриваючи перед нею шлях Аосягнення божої подоби) і Останньою Таємницею (заснованою на принципово новому вченні Мамлєєва про Безодню, котра цежить поза Абсолютом і в якій Аіє протилежний щодо Абсолюту принцип Ночі). Особливість Росії, отже, полягає в тому, що вона в самій своїй суті є Таємницею: «... “останні відносини” - це таємниця таємниць - найкраще можуть виразити себе саме потаємним шляхом “потаємної історичної Росії”. I ця прихована, остання якість робить Росію абсолютно першою. Сама присутність цього таємного рівня і забезпечує Росії іï космологічне й вічне існування. Росія стає не Аише носієм Безодні, але й носієм вищої таємниці» [Мамлеев, 2011, с. 215-216]. Тобто «таємничість» є невіА'ємною властивістю Росіі, іï визначальною характеристикою, що формує власну традицію, яку Мамлєєв позначає як традицію «шукання Росії. Таку Таємницю неможливо відокремити віА самої Росії, а тому доцільно говорити про неї як про Росію-Таємничю. Таке визначення не мише поєднує Росію і Таємницю, але й демонструє «метафізичну невловимість» Росії та підкреслює момент жаги АО позамежного як кАючову якість «російської Ауші».

Така увага до Росії як до однієї з центральних філософських проблем - стійкий мотив російської фінософії, який, як ми бачимо, не зникає безслілно у XIX столітті, а отримує своє продовження у «раАянському езотеричному піАпілАі», у межах якого Мамлєєв і сформував вцасну філософську Аумку, ставши, зокрема, засновником Южинського містично-езотеричного гуртка. Водночас необхіАним виАається АосліАження мамлєєвських розробок у контексті російської релігійної філософії ХІХ століття з метою визначення можливості чи неможливості продовження «втраченої» традиції, іiі трансформації та оновлення. 3 огляду на все зазначене вище питання залученості Мамлєєва до mрадичї російської фiлософії постає дуже гостро, аАже хто він, як не справжній спадкоємець Бердяєва, Хом'якова, Федорова та інших відомих російських мислителів?

У nidсумку можна зазначити, що поняття «хаосмосу», залучене до мамлєєвської творчості, є вкрай продуктивним, оскільки формує нову формулу «Хаос - Осмос Космос». Ця формула наАає можливість Аля розвитку таких важливих Аля Мамлєєва категорій, як Сакральний Хаос, російське буття, а також «космологічна Росія» як один із вимірів Росії Вічної (традиція російського космізму). Також слід зазначити, що Таємниця не може бути чітко локалізована в «структурі» мамлєєвського хаосмосу, аАже вона є всепроникливим елементом останнього. Роль Таємниці полягає в поєАнанні інших метатем творчості Мамлєєва: утризму «Я», Смерті, Безодні, Росії. Особливість Авох останніх призводить до необхідності введення понять «Остання Таємниця» та «Росія-Таємниця». «Остання Таємниця» стає втіленням граничності та позамежності Безодні, котра не знаходиться в площині Абсолюту, а межить поза ним. Зі свого боку «Росія-Таємниця» позначає невіл'ємну ознаку російського буття та культури - Ауховні та метафізичні пошуки власної Вітчизни, а також акцентує увагу на тому, що Мамлєєв наділяє Росію статусом третього метафізичного Початку поряд з Абсолютом і Безоднею. 


\title{
СПИСОК ВИКОРИСТАНИХ АЖЕРЕА
}

Гончаров С. Творча спаАщина Юрія Мамлєєва: філософія і / або мітература? Вісник Харківського наміонального університету імені В. Н. Каразіна. Серія «Філософія. Філософські nepunemiï». 2019. Вип. 61. С. 72-78. DOI: https://doi.org/10.26565/2226-0994-2019-61-8.

Гончаров С. Утризм «Я» Юрія Мамлєєва як особливий вил метафізики. Вісник Харківського начіонального університету імені В. Н. Каразіна. Серія «Філософія. Філософські nepunemiï». Вип. 62. 2020. С. 139-147. DOI: https://doi.org/10.26565/2226-0994-2020-62-15.

Ажойс $А$. Уэйк финнеганов / пер. с англ. А. Г. Волохонский. Тверь: Kolonna Publications, 2000. 128 c.

Кордас О., Николаева Ю. Феномен тайны в философском контексте. Вестник Омского государственного педагогического университета. Гуманитарныле исследования. 2015. № 2(6). C. 15-18.

Мамлеев Ю. Мир и хохот. М.: АСТ: Зебра Е, 2008. 315 с.

Мамлеев Ю. Россия Вечная. М.: Эксмо, 2011. 512 с.

Мамлеев Ю. Судьба бытия. М.: Эннеагон, 2006. 262 с.

Марджи Н. Тайна как эстетическая категория. Вестник Российского университета дружбъг народов. Серия «Философия». 2017. Т. 21. № 2. С. 280-282. DOI: https://doi.org/10.22363/23132302-2017-21-2-280-282.

Отто Р. Священное / пер. с нем. А. Руткевич. СПб: ИзА-во Санкт-Петербургского ун-та, 2008. 272 с.

Теория метафоры: сборник / пер. с англ., фр., нем., исп., польск. яз.; вступ. ст. и сост. Н. А. Арутюновой; общ. реА. Н. А. Арутюновой, М. А. Журинской. М.: Прогресс, 1990. 512 c.

Франк С. Сочинения. М.: Правда, 1990. 608 с.

\section{Гончаров Семен ОАексійович}

аспірант, фікософський факультет

Харківський національний університет імені В. Н. Каразіна

м. Свободи, 6, Харків, 61022

E-mail:sementulpanov@gmail.com

ORCID: https://orcid.org/0000-0001-8116-0804

Стаття надійшла Ао редакції: 20.10.2020

Схвалено Ао Аруку: 23.11.2020

\section{THE ROLE AND PLACE OF THE MYSTERY IN METAPHYSICS OF MAMLEEV'S CHAOSMOS}

\section{Honcharov Semen A.}

PhD Student, Faculty of Philosophy

V. N. Karazin Kharkiv National University

6, Svobody sqr., 61022, Kharkiv, Ukraine

E-mail: sementulpanov@gmail.com

ORCID: https://orcid.org/0000-0001-8116-0804

\begin{abstract}
The article examines the role and place of the Mystery within the structure of Mamleev's metaphysics. The author of the article implicates the concept of "chaosmos", introduced by James Joyce in the experimental novel "Finnegans Wake", to the Mamleev's Universe. This leads to the transformation of the formula "chaos - osmosis - cosmos", actualized by postmodern discourse, into the formula "Chaos - Osmosis - Cosmos". Chaos here is Sacred Chaos, being one of the metaphysical manifestations of Eternal Russia. Osmosis appears to be an antinomic Russian life, which combines the incompatible, and sets itself fundamentally impossible tasks. The Cosmos brings us to the tradition of Russian cosmism
\end{abstract}


with its problem of microcosm and macrocosm conformity. The author of the article points out that the all-pervading and unifying element of Mamleev's chaos is the Mystery. It is one of the five key metathemes of Mamleev's oeuvre. The particularity of the Mystery is that it provides a link between other metathemes: utrism "I", Death, the Abyss and Russia. In the plane of utrism "I" the Mystery is seen as the mystery of man (his higher "I"). The Mystery is related to Death by the person's interest of his own destiny and finiteness. The problem of overcoming death and the passion for eternal life are the central themes that concern almost all the heroes of Mamleev's novels and short stories. For Mamleev they are the source of values aimed at the human need to achieve a higher "I". The connection between the Mystery and the Abyss, as well as the connection between the Mystery and Russia are the strongest and the most important for Mamleev. Consideration of these connections prompts the author to conclude that Yuri Mamleev describes such dimensions of the Mystery, which go beyond the categories "unfathomable-to-us" and "unfathomable-in-itself", introduced by S. Frank. This requires the introduction of new concepts that would bring out the essence of Mamleev's innovations. The author of the article proposes to consider the Abyss as a "Last Mystery" by the fact it is transcendent to the transcendents themselves, that is it goes beyond the Absolute, as well as to consider Eternal Russia as a Russia-Mystery on the grounds that Mamleev gives it the status of the third metaphysical Beginning, along with the Absolute and the Abyss.

Key words: Mamleev, Mystery, Abyss, chaosmos, unfathomable, cosmism.

\section{REFERENCES}

Arutsunova, N. D., \& Zhurinskaia, M. A. (Eds.). (1990). The Theory of Metaphor: Collected Works. Moscow: Progress. (In Russian).

Frank, S. (1990). Works. Moscow: Pravda. (In Russian).

Honcharov, S. (2019). Yuriy Mamleev's Creative Writings: Philosophy and/or Literature? The Journal of V.N. Karazin Kharkiv National University, Series "Philosophy. Philosophical Peripeteias”, 61, 72-78. (In Ukrainian). DOI: https://doi.org/10.26565/2226-0994-201961-8.

Honcharov, S. (2020). Mamleev's I-utrism as a Special Kind of Metaphysics. The Journal of V. N. Karazin Kharkiv National University, Series "Philosophy. Philosophical Peripeteias", 62, 139147. (In Ukrainian). DOI: https://doi.org/10.26565/2226-0994-2020-62-15.

Joyce, J. (2000). Finnegans Wake. (A. Volokhonsky, Trans.). Tver: Kolonna Publications. (Original work published 1939). (In Russian).

Kordas, O., \& Nikolaeva, J. (2015). Phenomenon of Mystery in Philosophical Context. The Journal of Omsk State Pedagogical University, Humanitarian Research, 2/6, 15-18. (In Russian).

Mamleev, Yu. (2008). World and Laughter. Moscow: AST: Zebra E. (In Russian).

Mamleev, Yu. (2009). The Destiny of Being. Moscow: Enneagon. (In Russian).

Mamleev, Yu. (2011). Eternal Russia. Moscow: Eksmo. (In Russian).

Mardzhi, N. (2017). The Mystery as Aesthetic Category. RUDN Journal of Philosophy, 21(2), 280282. (In Russian). DOI: https://doi.org/10.22363/2313-2302-2017-21-2-280-282.

Otto, R. (2008). The Idea of the Holy. (A. Rutkevich, Trans.) Saint Petersburg: Saint Petersburg University Publishing House. (Original work published 1917). (In Russian).

Article arrived: 20.10 .2020

Accepted: 23.11.2020 